\title{
Mass balance of glaciers in the Queen Elizabeth Islands, Nunavut, Canada
}

\author{
Roy M. KOERNER \\ Geological Survey of Canada, 601 Booth Street, Ottawa, Ontario K1A OE8, Canada \\ E-mail: rkoerner@nrcan.gc.ca
}

\begin{abstract}
Mass-balance measurements began in the Canadian High Arctic in 1959. This paper considers the $\mathbf{7 0}$ years of measurements made since then, principally on two stagnant ice caps (on Meighen and Melville Islands), parts of two ice caps (the northeast section of Agassiz Ice Cap on northern Ellesmere Island and the northwest part of Devon Ice Cap on Devon Island) and two glaciers (White and Baby Glaciers, Axel Heiberg Island). The results show continuing negative balances. All the glaciers and ice caps except Meighen Ice Cap show weak but significant trends with time towards increasingly negative balances. Meighen Ice Cap may owe its lack of a trend to a cooling feedback from the increasingly open Arctic Ocean nearby (Johannessen and others, 1995). Feedback from this ocean has been shown to be the main cause of this ice cap's growth and persistence at such a low elevation of $<300$ m a.s.l. (Alt, 1979). There may be a similar feedback in the lower elevations on Sverdrup Glacier which drains the northwest sector of Devon Ice Cap. The ablation rates there have not increased to the same extent as they have at higher elevations on the same glacier. Although evidence from the meteorological stations in the area shows that the eastern Arctic has either been cooling or has shown no change on an annual basis between 1950 and 1998, the same records show that the summers are showing a slight warming (Zhang and others, 2000). The summer warming, although slight $\left(<1.0^{\circ} \mathrm{C}\right.$ over 48 years), is the cause of the weak trend to increasingly negative balances. This is because the massbalance variability is dominated by the year-to-year variations in the summer balance; there is a very low variability, and no trend over time even within sections of the time series, of the winter balance of the various ice caps and glaciers. Repeat laser altimetry of ice caps by NASA for the period 1995-2000 over most of the ice caps in the Canadian Arctic Archipelago (Abdalati and others, 2004) has shown that the ablation zones are thinning while the accumulation zones show either a slight thickening or very little elevation change. Laser altimetry is revealing similar patterns of change in Greenland (Krabill and others, 2000) and Svalbard (Bamber and others, 2004). The thickening of the accumulation zones in the Canadian case may be due to higher accumulation rates, not just between the two years of laser measurements, but over a period substantially longer than the $>\mathbf{4 0}$ years of ground-based measurements.
\end{abstract}

\section{INTRODUCTION}

In terms of present climatic change, glaciers are of especial importance for: (1) detecting trends in their mass balance; (2) finding how those trends apply across the various elevations covered by the ice caps, and (3) placing climatic change into a longer context back in time. This paper will consider these three topics and, in addition, discuss the new techniques introduced into the accumulation zone to replace a methodology which has become inadequate due to the climatic changes that have occurred there over the past four decades.

In pursuit of these aims, the results of $>40$ years of massbalance results from the Queen Elizabeth Islands, Nunavut, Canada, (Fig. 1) are used, with the greatest emphasis on the northwest side of Devon Ice Cap. That record is not only one of the most continuous, but covers $>40$ years and spans a greater elevation range than any other record globally. The data from the northern part of Agassiz Ice Cap on northern Ellesmere Island ('Drambuie Glacier') are shown for comparative purposes only. They do not yet include the complete accumulation area and represent only elevations of $400-1300 \mathrm{~m}$. These data are from a section primarily situated in the ablation zone and do not incorporate area, i.e. the balance rates illustrated in Figure 2 and Table 1 are two-dimensional. Details of the methods used in the measurements and the nature of the stake networks may be found in Koerner (1977), Cogley and others (1995) and Koerner and Lundgaard (1995).

While there are other sources for accessing these data, they should preferably be accessed through the author (rkoerner@nrcan.gc.ca), because additional measurements are presently being incorporated to improve the various datasets.

\section{GLACIER MASS-BALANCE TRENDS}

The results from the Canadian Eastern Arctic dataset are shown in Figure 2. The mean balance on all the ice caps and glaciers is negative (Table 1 ). There is a very weak trend towards increasingly negative balances over the approximately 40 year period except on Meighen Ice Cap. The strongest trend appears in the north Agassiz Ice Cap data (Fig. 2; Table 1). However, this is largely due to the fact that, as mentioned previously, area has not yet been included in the derivation of mass balance, so that the large area in the accumulation zone does not dampen the trend as it does in the other time series.

There is a slightly stronger trend within the time series, towards increasingly negative balances between 1980 and 2000 (Table 1). With the occurrence of a very negative 


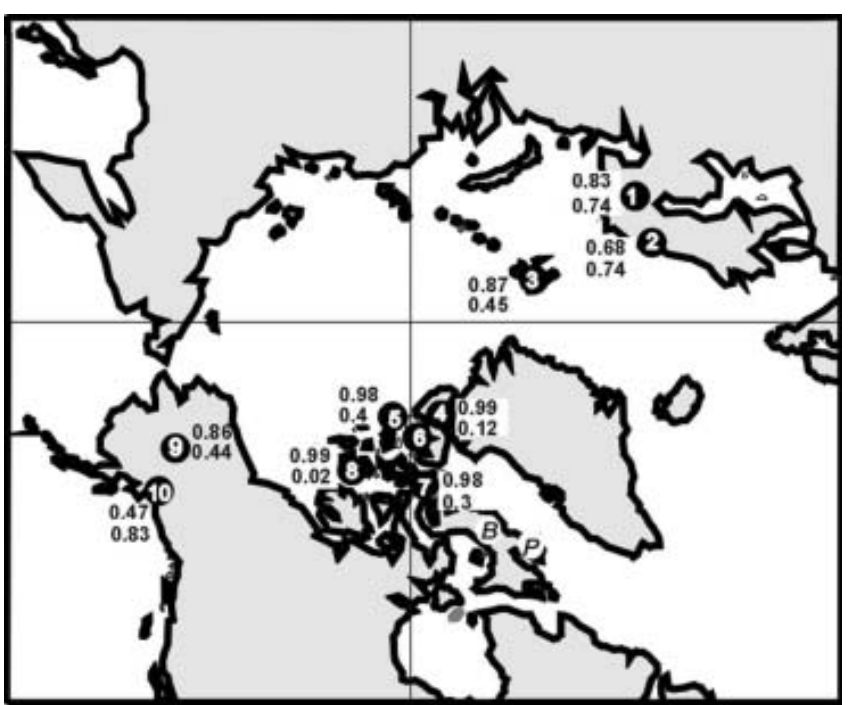

Fig. 1. Glaciers and ice caps in the circum-Arctic discussed in the text: 1. Storglaciären, Sweden; 2. Engabreen, Norway; 3. austre Brøggerbreen, Svalbard; 4. Agassiz Ice Cap, northern Ellesmere Island, Canada; 5. Meighen Ice Cap, Canada; 6. White and Baby Glaciers, Axel Heiberg Island, Canada; 7. Devon Ice Cap, Canada; 8. Melville South Ice Cap, Canada; 9. Gulkana Glacier, Alaska, USA; 10. Wolverine Glacier, Alaska, USA. The uppermost number by each location is the $r$ value for the relationship between summer and net balance; the lower value is that between winter and net balance. ' $\mathrm{B}$ ' is Barnes Ice Cap, and ' $\mathrm{P}$ ' is Penny Ice Cap.

balance in 2001 it was thought that this trend was becoming well established. However, both the 2002 and 2003 summers have weakened this trend. In fact, occurrences of single very negative balance years (e.g. 1962) have a much more disproportionate effect on trends and can cancel out the effect of several positive balance years. For example, the negative balance of the three warmest summers on the northwest side of Devon Ice Cap (1962, 1998, 2001) together cancels out the combined effect of all the positive balance years in the 43 year period.

There is no trend in the winter balance, and the year-toyear variability is very low (Fig. 2; Table 1). This is surprising, as modeling predicts an increase in precipitation with increasing temperatures. Consequently, the net balance variability is determined almost entirely by the variability of summer climate. Figure 1 and Table 1 show the correlation coefficients between net balance and the summer and winter balances. Throughout the Queen Elizabeth Islands the values for summer are equal to, or above, 0.98 whereas, apart from Meighen Ice Cap, winter

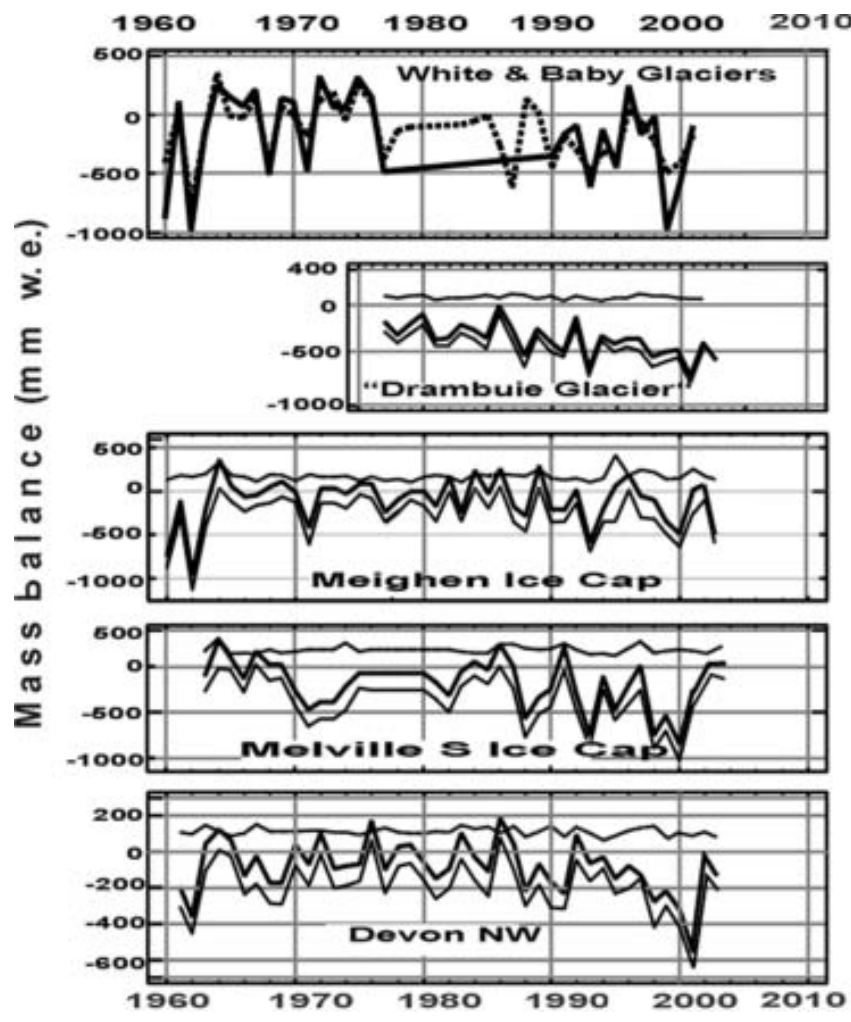

Fig. 2. Winter, summer and net balance for glaciers in the Queen Elizabeth Islands. Winter and summer balance is not available for White (dashed line) and Baby Glaciers (solid line). In the other glaciers the upper line is winter balance, the middle is net balance and the lower is summer balance. The values for 'Drambuie Glacier' are two-dimensional, i.e. area is not included. They do not extend to the top of the accumulation area. The final values are therefore not comparable in magnitude to those for the other four glaciers where area is considered and the entire elevation interval is sampled; the values are included for comparing trends among the glaciers.

balance plays almost no part in the changing values of net balance from year to year. Since the summer balance is determined over a short, 2-3 month period and need not follow annual temperature trends, caution is urged in using annual temperatures to measure the effect of changing climate and its effects on glaciers in regions such as the Canadian High Arctic. Elsewhere (e.g. in the less continental types of climate in Alaska, Svalbard and northern Scandinavia) the influence of summer climate in determining the net balance variability is not as strong (Fig. 1) and the south coast of Alaska even shows a dominance of winter balance.

Table 1. Period measured, cumulative mass balance, and regression values between various balance parameters on the ice caps in the Canadian High Arctic considered in the text

$\begin{aligned} & \text { Devon Ice Cap } \\ & \text { northwest }\end{aligned} \quad$ Meighen Ice Cap Melville South Ice Cap $\quad \begin{aligned} & \text { Agassiz Ice Cap } \\ & \text { north }\end{aligned}$ White Glacier

\begin{tabular}{|c|c|c|c|c|c|}
\hline Period measured & 1961-2003 & 1960-2003 & 1963-2003 & 1977-2003 & 1960-2003 \\
\hline Number of years & 43 & 44 & 41 & 27 & 41 \\
\hline Cum. balance (m) & -3.54 & -4.54 & -7.24 & n.a. & -5.6 \\
\hline$r$ value $\mathrm{S}$ vs Net & $0.98(99 \%)$ & $0.98(99 \%)$ & $0.99(99 \%)$ & $0.975(99 \%)$ & n.a. \\
\hline$r$ value W vs Net & n.s. & $0.41(99 \%)$ & $0.36(95 \%)$ & n.s. & n.a. \\
\hline$r$ value Net vs Time & $0.29(90 \%)$ & n.s. & $0.36(95 \%)$ & $0.63(99 \%)$ & $0.27(90 \%)$ \\
\hline
\end{tabular}




\section{THE EFFECT OF CLIMATIC WARMING ON METHODOLOGY IN THE ACCUMULATION ZONE}

I briefly define the various zones (originally facies under Benson's (1961) classification) in the accumulation area. The uppermost zone, where there is no melt, is termed the dry snow zone. Below this in the percolation zone, melt refreezes within the surface annual layer, where it is generally termed internal accumulation. The saturation (or wet snow) zone has a lower boundary at the firn line and is where meltwater penetrates below the surface annual layer and refreezes as internal accumulation. In the lower elevations of this zone, some meltwater may run off to emerge at the firn line where it may refreeze within the superimposed ice zone. The superimposed ice zone lies between the firn and equilibrium lines (where accumulation equals ablation) and accumulation is in the form of ice formed from refrozen melt. Over the 40 year period, Agassiz and Devon Ice Caps and White Glacier have, in some years, included all these zones. Meighen and Melville Ice Caps rarely reach above the saturation zone. As a consequence, the methods discussed here refer to Agassiz and Devon Ice Caps where the Geological Survey of Canada conducts the measurements.

Measurement of the mass balance in the dry and percolation zones can be achieved by making depth/density measurements of the surface annual layer formed after the end of the previous melt season to give the winter balance, and thickness/density measurements of the underlying annual layer to give the net balance. The summer balance is then the difference between the net and winter balances. A board placed at a set distance and direction from the stake on the surface each spring simplifies these measurements. The saturation zone, however, is problematic because even if a board is placed on the surface each spring, meltwater percolates below it in the following summer. Even the use of dyes makes it difficult to recognize and quantify the amount of internal accumulation that has percolated into lower annual layers. Our practice has been to use percolation trays. The tray, placed each spring on the previous summer surface, retains meltwater in the ensuing summer that would otherwise have percolated down into deeper years of accumulation. The lower parts of the same zone are unmanageable, as the trays overflow, thereby presenting the very problems the tray is meant to avoid. Stake measurements on their own are inadequate and are only of value in determining if there is a smooth transition in stake length (shortening) from the percolation zone above, through to the superimposed ice zone below. A smooth change in stake height justifies interpolation across the problem area, although this is not always the case. I stress here that the errors in the saturation zone are solely in terms of summer accumulation, as the winter balance, consisting of a surface layer of dry snow at the time of measurement, is measured accurately each spring.

Since the mid-1980s the tray method on Devon Ice Cap has had restricted use. This is due to the expansion, in some years, of the saturation zone over much of the accumulation area, with a large part of that zone undergoing sufficient melt to overflow the trays. Before the mid-1980s, Devon Ice Cap would have a dry snow zone in its upper elevations about one year in ten (three in ten on northern Ellesmere Island). Since then, the saturation zone has extended throughout the accumulation zone above the firn line in about seven years in ten on Devon Ice Cap, and five years in

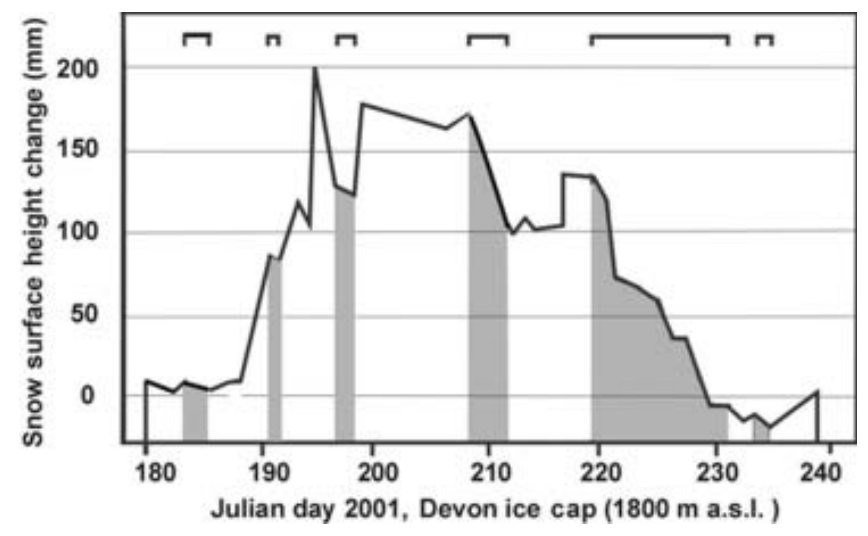

Fig. 3. Changing snow surface height during the 2001 melt season, Devon Ice Cap (1800 ma.s.I.). The intervals shaded grey represent periods of melting when the surface was lowered by melt. The open brackets at the top denote periods of melt.

ten on northern Ellesmere Island. This means that a large part of the accumulation zone would become unmanageable if we continued to rely only on the tray method.

Automatic weather stations (AWSs) have replaced the tray technique in an effort to overcome the problem of measuring internal accumulation. Campbell equipment is used with only two sensors: one to measure the distance to the snow surface ultrasonically, and the other to measure temperature. The combination of these two sensors allows the measurement of the change of snow depth above the previously measured summer surface whether due to snowfall, snowdrift or melting. Accumulation by rainfall cannot be detected. However, at the elevations we are considering, i.e. the lower parts of the saturation zone at 1500-1800 m on Devon Ice Cap for example, rainfall is unusual.

The method is as follows. Using the AWS records, increasing accumulation (i.e. a shortening of the distance between the snow surface and the ultrasonic sensor), whether due to snowdrift or solid precipitation (Fig. 3), is summed for the period between the spring in situ measurements and the end of the melt season. An increase in the distance between the snow surface and the sounder will only represent a loss of accumulation if the temperature stays below $0^{\circ} \mathrm{C}$. In this case, the change is negative and the values are subtracted from the previously summed values. If the temperature during a lowering of the surface stays above $0^{\circ} \mathrm{C}$ (shaded areas in Fig. 3), the change is attributed to melting which percolates into the snowpack, either refreezing as ice layers or increasing the firn/snow density. There is then no loss of accumulation and no changes are made to the algebraic sum of the changes up to that point in the record. The effect of settling over this period is small and is essentially the settling over the depth interval of the AWS mast buried in the snow/firn over the 2-3 month period.

The main error in this system is that the measurement does not incorporate snow density. Density therefore has to be estimated. A rapid change in snow-sounder height, indicating accumulation (Julian day 217; Fig. 3), is attributed to new snowfall with an estimated density of $150 \mathrm{~kg} \mathrm{~m}^{-3}$. Slower changes, due most likely to snowdrift (Julian days 235-239), are attributed a density of $200 \mathrm{~kg} \mathrm{~m}^{-3}$. These are qualitative assignments based on experience gained in this region from $>40$ years of measurements. One would expect the density error to be of the order of $\pm 50 \mathrm{~kg} \mathrm{~m}^{-3}$. 


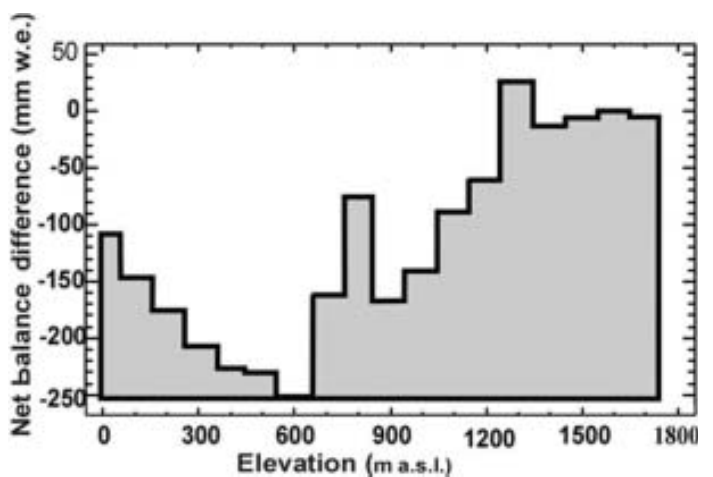

Fig. 4. The difference in net balance (mm w.e.) between the 196194 and 1995-2000 periods.

Cogley and Adams (1998) have discussed the errors introduced into mass-balance measurements due to poor assessment of internal accumulation. They quote values from McCall Glacier and Barnes Ice Cap of internal accumulation rates of 56 and $51 \mathrm{~mm} \mathrm{a}^{-1}$. They conclude internal accumulation has a typical magnitude of tens of millimeters on glaciers whose mass-balance magnitude is a few times larger'.

Using the AWS data depicted schematically in Figure 3, we find that stake measurements made in spring would indicate a drop in surface level of $30 \mathrm{~mm}$ between the measurement made of the snow surface in the first spring and of the position on the stake of the summer melt surface (easily recognized by its hardness and texture) the following spring. However, the AWS indicates that accumulation (algebraic sum of snowdrift accumulation (positive) and snowdrift deflation (negative)) adds up to $191.5 \mathrm{~mm}$. Using mean densities of 100 and $300 \mathrm{~kg} \mathrm{~m}^{-3}$, which would be a generously broad range of values, we calculate an accumulation of $28.7-57.3 \mathrm{~mm}$ w.e. If we consider a maximum area saturation zone covering the entire area above the firn line on the northwest side of Devon Ice Cap $\left(226 \mathrm{~km}^{2}\right)$, we obtain a summer balance in the saturation zone of $(0.65-1.29) \times 10^{-2} \mathrm{~km}^{3}$. This compares to a total balance in the year ending in summer 2001 of $-94.89 \times 10^{-2} \mathrm{~km}^{3}$. If we assume an error, due to estimating the density, equal to the difference between the two estimates, i.e. $0.64 \times 10^{-2} \mathrm{~km}^{3}$, this error becomes $<1 \%$ of that final balance. In a cooler summer, where the saturation zone does not cover the entire accumulation area above the firn line, the error would be somewhat less. However, although the error is small, a sensor capable of measuring snow mass change would be a welcome improvement on the present ultrasonic distance sensor.

\section{RELATIONSHIP BETWEEN MASS BALANCE, EQUILIBRIUM-LINE ALTITUDE (ELA) AND THE BALANCE GRADIENT}

A simple predictor of mass balance is frequently sought after for extrapolation beyond the area of measurement or for detection on satellite images. Dyurgerov and Bahr (1999) have discussed at length the appropriate parameters for global glacier monitoring. Unlike their global study, we find a very good relationship $(r=0.91)$ between annual mass balance and the equilibrium-line altitude (ELA) on the northwest Devon Ice Cap balance network, to which I restrict this discussion as it covers the greatest elevation range. There is a slight non-linearity in this relationship as the ELA approaches the elevation of the long-period firn line, which it has exceeded in two years (with small meltstreams emerging from beneath the firn). The ELA on northwest Devon Ice Cap has also varied between 579 and 1570 ma.s.l. between 1961 and 2003, i.e. from slightly above the firn line to below the edge of the ice-cap margin on the northwest side. In the latter case, snow on the adjoining plateau meant the firn/snow line was located beyond the icecap margin. However, the advantages of finding and using the equilibrium line are limited. The main limitation is it still requires an assemblage of stakes to determine its elevation. As its elevation may vary over such a wide range, the savings in time would be minimal. It also seems unlikely any sensor on the present set of satellites could detect it. This is because superimposed ice exists both above and below the equilibrium line in most years. The ice that forms above the equilibrium line moves below it in time.

Because there is only rarely a balance gradient (balance vs elevation) above the firn line, or indeed often above the equilibrium line, I limit the term balance gradient in this discussion to that part of the ice cap below the equilibrium line. The balance gradient on the smaller, narrow-elevationrange Meighen and Melville Ice Caps is related to distance from the ice-cap edge as well as to elevation. Therefore, in this context, I again confine further discussion of this topic to the northwest Devon Ice Cap where there is usually an elevation range of $>1000 \mathrm{~m}$ between the equilibrium line and sea level.

Over the 43 year record, no simple relationship has been found between the balance gradient below the equilibrium line and net balance. In fact, the balance gradient is often non-linear and can be broken up into as many as three linear parts. This has some implications, especially with respect to the varying response of different elevation ranges on the same glacier to climatic change.

In the process of determining the typicality of the 19952000 period when laser altimeter measurements were made over the Arctic glaciers and ice caps (Abdalati and others, 2004), the 5 year period net balance on northwest Devon Ice Cap was compared to that for the preceding 35 year period. The results are shown in $100 \mathrm{~m}$ elevation band intervals in Figure 4. Firstly, there is very little balance change in the accumulation zone. Below the equilibrium line and down to $600 \mathrm{~m}$ elevation, the differences between the 35 and 5 year periods become increasingly negative, i.e. increased melting producing more negative balances in the 5 year period. Below $600 \mathrm{~m}$, however, with decreasing elevation to sea level, the differences become smaller (Fig. 4). This has prompted a more detailed study of the rate of change, over 43 years, of the Devon Ice Cap net balance in each $100 \mathrm{~m}$ elevation interval below the equilibrium line for the 43 years of measurements. The results are shown in Figure 5. The greatest rates of change lie between 300 and $700 \mathrm{~m}$ elevation (on Sverdrup Glacier which is the outlet glacier in the northwest part of Devon Ice Cap). Above $650 \mathrm{~m}$, the absolute differences in net balance would be expected to decrease with approach to the equilibrium line, which has been situated on average over the 43 year period at $1100 \mathrm{~m}$ elevation. This is the case we find. Below $350 \mathrm{~m}$, however, there appears to be an effect that limits the increase of ablation rates between 1961 and 2003 (Figs 4 and 5). A 


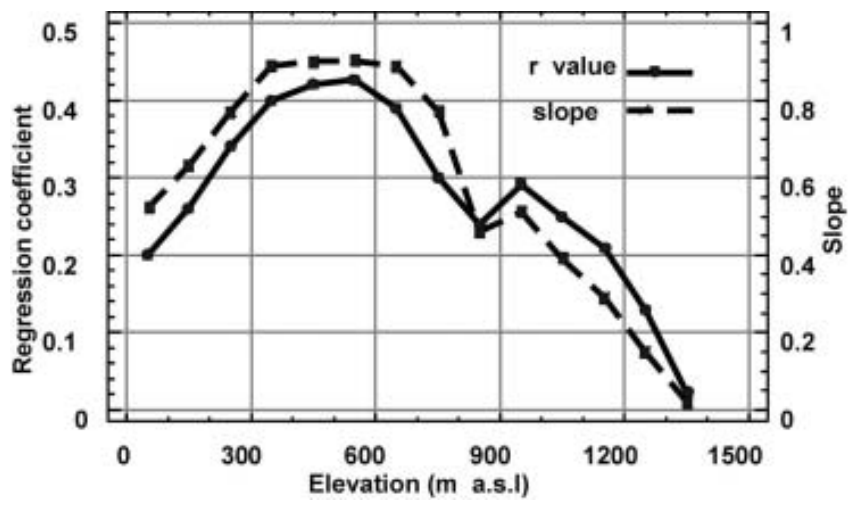

Fig. 5. Results of linear regression analysis of glacier net balance vs time by $100 \mathrm{~m}$ elevation intervals, on the northwest side of Devon Ice Cap, 1961-2003. Slope is the $b$ coefficient in the linear relationship and represents the negative balance change per year over the period.

strong possibility is the effect of increasing open water in summer in Jones Sound into which Sverdrup Glacier flows. Fog, indicative of colder, moister air, has often been observed ascending the glacier from Jones Sound in the summer months; this incidence may be increasing. Alt (1979) attributed the origin and persistence of Meighen Ice Cap at unusually low elevations to the movement of stratiform clouds and cold air from the Arctic Ocean onto the ice cap, where it formed melt-suppressing fog. Similarly, the Ward Hunt and other ice shelves persist at sea level along the northern coast of Ellesmere Island partly due to very low summer ablation rates associated with the cooling effect of the nearby Arctic Ocean (Crary, 1960; Jeffries, 2002). If a nearby ocean/sea effect is responsible for melt suppression at the lower elevations of Sverdrup Glacier, it may have implications for models applying sea-level temperatures and constant temperature lapse rates for calculating glacier balance gradients. The phenomenon warrants further investigation.

\section{PUTTING MASS BALANCE INTO PERSPECTIVE}

Because summer climate plays such a strong part in determining changes in the net balance in the Canadian High Arctic, ice-core records from two of these ice caps can be used to put modern mass balance into a longer-term context. The derivation and limitations of the climate and mass-balance proxies from ice cores can be found in Koerner (1977) and Koerner and Fisher (1990). Koerner (1977) found a significant relationship between the amount of melting each year, in a core from the top of the accumulation zone on Devon Ice Cap, and the 14 year mass-balance record on its northwest side. The entire core gave a 700 year record of ice-melt features. A longer summer melt record covering the entire Holocene period was then developed using a core from Agassiz Ice Cap (Koerner and Fisher, 1990). Together these records (Fig. 6) stress the increasing warmth of the modern period, beginning in the mid-19th century. However, the Agassiz Ice Cap ice-core record also suggests greater warmth in the early part of the Holocene (Koerner and Fisher, 2002; Fisher and Koerner, 2003). The conclusion from this, and the present work, is that the mass balance of the northwest part of Devon Ice

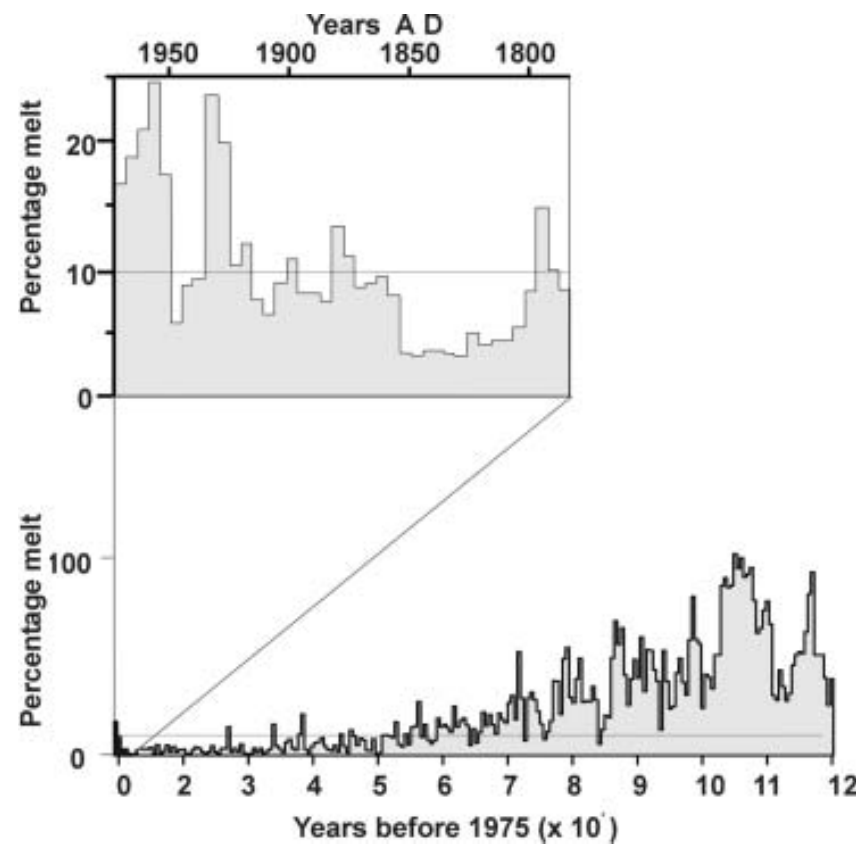

Fig. 6. Percentage melt from the combined ice-core records from Agassiz Ice Cap (1780 ma.s.I.) and Devon Ice Cap (1750 m a.s.I.). The horizontal line $(10 \%$ melt) represents the approximate value for a zero net balance on the northwest sector of Devon Ice Cap. Above that line, there would have been a generally negative balance, and below it a positive balance.

Cap, and probably a large part of the Queen Elizabeth Islands as a whole, has been mildly negative for the last 100 years, but has become increasingly negative in the last 50 years. However, the balance is still not as negative as it was in the early Holocene period 10000 years ago.

\section{NEW APPROACHES TO MEASURING GLACIER BALANCE}

With the advent of remote-sensing techniques, the traditional method of measuring mass balance is not only being supplemented with much more broad-based techniques but, assuming continued improvement in technology, may eventually be replaced by them. For example, Reeh and others (2002) have discussed the derivation of ablation rates by combining airborne laser altimetry measurements with emergence/submergence velocities derived from satellite synthetic aperture radar interferometry. Comparison of their remotely sensed values with in situ measurements proved 'satisfactory' (Reeh and others, 2002) inasmuch as an accuracy of $0.5 \mathrm{~m} \mathrm{a}^{-1}$ can be attained for ablation rates. On the northwest side of Devon Ice Cap, only that part of the ice cap below 650 m exceeds this ablation rate; $50 \%$ of the total ablation occurs above $650 \mathrm{~m}$ at rates $<0.5 \mathrm{~m} \mathrm{a}^{-1}$. Such an approach, to be satisfactory in high-latitude areas with lowactivity glaciers, must await further improvements in satellite techniques and their application to glacier mass balance.

Recently, there have been two projects assessing the mass balance of the Canadian Eastern Arctic using remote-sensing techniques. The first (Sharp and others, 2004) measured changing ice-cap/glacier area, based on comparisons between aerial photography in 1959/60 and satellite imagery in 1999/2000. The second (Abdalati and others, 2004) 
measured elevation changes by repeat airborne laser altimetry in each of the years 1995 and 2000. It is not the purpose here to compare these data with the in situ data, as they cover different areas and have quite different approaches in calculating volumes. However, in terms of sea-level contributions from the Queen Elizabeth Islands ice caps, the two studies show similar values: $0.036 \mathrm{~mm} \mathrm{a}^{-1}$ (Sharp and others, 2004) and $0.046 \mathrm{~mm} \mathrm{a}^{-1}$ (Abdalati and others, 2004). Considering the first estimate is based on the 195999 period and the second on the 1995-2000 warmer period, they show remarkable agreement.

The laser altimetry work over the Canadian Arctic Archipelago was one of many such exercises by NASA in the circumpolar region. The general picture from these measurements (Krabill and others, 2000; Abdalati and others, 2004; Bamber and others, 2004) is that the central parts (accumulation zones) of the ice caps and the Greenland ice sheet are thickening, whereas there is extensive thinning around their margins, i.e. the ablation zones.

Unusually high or low winter balances can affect the altimetry measurements in each of the two years of measurement. High or low net balances in each of the years of measurement may also affect them. Snow-density variations will also affect elevation changes, particularly above the firn line. With respect to the northwest sector of Devon Ice Cap and along the Agassiz Ice Cap network, the 1995-2000 period had more negative balances, due to warmer summers, than the previous 35 year mean. Thus, the densities measured in the firn zone on both Agassiz and Devon Ice Caps were higher, on average, during that period due to higher snow/firn melting rates. The in situ measurements showed no evidence for higher accumulation rates in the 5 year period. Thus, the slight thickening found in the accumulation zone of many of the ice caps in the Canadian Arctic Archipelago by the laser altimetry is slightly puzzling. However, the difference between the two years of altimetry measurements also incorporates the effect of the vertical strain rate on elevation change. Differences between the 1995 and 2000 laser altimeter elevations are essentially the differences between the mass balance and the vertical strain rate. This is because there is no evidence for past or present surging (which might introduce an additional dynamic effect on elevation change) in the areas measured by the in situ method, where this discussion is focused. As no differences between the 5 and 40 year accumulation rates are evident (Fig. 4), and the measured density differences would cause a slight elevation decrease, the increase in thickness in some areas is most likely due to a higher accumulation rate over a period longer than 40 years, to which the vertical strain rate has not yet adjusted.

While the laser altimetry measured significant thinning in the ablation zones of all the ice caps in the Canadian Arctic Archipelago, these rates reached a maximum on the more southerly Penny and Barnes Ice Caps on Baffin Island. Barnes Ice Cap showed the greatest thinning rates, most likely because it is essentially a relic of the last ice age with continuing negative balances throughout the Holocene (Fisher and Koerner, 2003).

\section{SUMMARY AND CONCLUSIONS}

Using traditional methods, mass-balance measurements from the Queen Elizabeth Islands over four decades indicate that the ice caps there have an overall negative balance.
There is evidence for a weak but significant trend to increasingly negative balances over the 1960-2003 period. Variations in the net balance are dominated by the summer climate, as the winter balance has shown very little change and low annual variability over that period. Warmer summers have increased the melting and depth of meltwater percolation in the accumulation area. The previous technique of using percolation trays to measure the mass balance above the firn line is no longer appropriate. Consequently, AWSs with temperature and snow sounders are now being used. They have improved the accuracy of the measurements so that the error introduced into the overall net balance, due to melt refreezing at depth, is calculated to be $<1 \%$.

While there is a high relationship between the ELA and the net balance in the area studied on Devon Ice Cap, this is not the case for the balance gradient below the equilibrium line. There is some evidence for 'melt suppression' at lower elevations on the outlet glacier from the northwest side of Devon Ice Cap, possibly due to an increasing incidence of lower-temperature, fog-bearing winds moving up that glacier from an increasingly open Jones Sound.

The future lies in the increasing use of remote-sensing techniques. Repeat laser altimetry and satellite area monitoring is already passing into the next phase of higherprecision, satellite altimetry. For this next stage (Drinkwater and Rebhan, 2003) a thorough ground control is presently being conducted although it also includes continuing use of the traditional method.

\section{ACKNOWLEDGEMENTS}

This work has been supported throughout by the Polar Continental Shelf Project, now of Natural Resources Canada. It is now also part of the Climate Change Program of Natural Resources Canada and has received funding, since 2001, from Action Plan Canada for improving the massbalance programme infrastructure. The author is indebted to two anonymous reviewers and C. Zdanowicz and G. Cogley for comments on an earlier version of the manuscript.

\section{REFERENCES}

Abdalati, W. and 9 others. 2004. Elevation changes of ice caps in the Canadian Arctic Archipelago. J. Geophys. Res., 109(F4), F04007. (10.1029/2003JF000045.)

Alt, B.T. 1979. Investigation of summer synoptic climate controls on the mass balance of Meighen Ice Cap. Atmosphere-Ocean, 17(3), 181-199.

Bamber, J.L., W.B. Krabill, V. Raper and J.A. Dowdeswell. 2004. Anomalous growth of part of a large Arctic ice cap: Austfonna, Svalbard. Geophys. Res. Lett., 31(12), L12402. (10.1029/ 2004GI019667.)

Benson, C.S. 1961. Stratigraphic studies in the snow and firn of the Greenland ice sheet. Folia Geogr. Dan., 9, 13-37.

Cogley, J.G. and W.P. Adams. 1998. Mass balance of glaciers other than the ice sheets. J. Glaciol., 44(147), 315-325.

Cogley, J.G., W.P. Adams, M.A. Ecclestone, F. Jung-Rothenhäusler and C.S.L. Ommanney. 1995. Mass balance of Axel Heiberg Island glaciers, 1960-1991: a reassessment and discussion. Saskatoon, Sask., Environment Canada. National Hydrology Research Institute. (NHRI Science Report 6.)

Crary, A.P. 1960. Arctic ice island and ice shelf studies, Part II. Arctic, 13(1), 32-50.

Drinkwater, M. and H. Rebhan. 2003. CryoSat science report. ESA Spec. Pap. 1272. 
Dyurgerov, M.B. and D.B. Bahr. 1999. Correlations between glacier properties: finding appropriate parameters for global glacier monitoring. J. Glaciol., 45(149), 9-16.

Fisher, D.A. and R.M. Koerner. 2003. Holocene ice-core climate history: a multi-variable approach. In Mackay, A., R. Battarbee, R. Birks, J. Oldfield and J. Arnold, eds. Global change in the Holocene. London, Arnold.

Jeffries, M.O. 2002. Glaciers of the Arctic islands. Ellesmere Island ice shelves and ice islands. In Williams, R.S., Jr and J. Ferrigno, eds. Satellite image atlas of glaciers of the world: North America. USGS Prof. Pap. 1386-J, J147-J164.

Johannessen, O.M., M. Miles and E. Bjørgo. 1995. The Arctic's shrinking sea ice. Nature, 376(6536), 126-127.

Koerner, R.M. 1977. Devon Island ice cap: core stratigraphy and paleoclimate. Science, 196(4285), 15-18.

Koerner, R.M. and D.A. Fisher. 1990. A record of Holocene summer climate from a Canadian high-Arctic ice core. Nature, 343(6259), 630-631.
Koerner, R.M. and D.A. Fisher. 2002. Ice-core evidence for widespread Arctic glacier retreat in the Last Interglacial and the early Holocene. Ann. Glaciol., 35, 19-24.

Koerner, R.M. and L. Lundgaard. 1995. Glaciers and global warming. Géog. Phys. Quat., 49(3), 429-434.

Krabill, W. and 9 others. 2000. Greenland Ice Sheet: high-elevation balance and peripheral thinning. Science, 289(5478), 428-430.

Reeh, N. and 6 others. 2002. Glacier specific ablation rate derived by remote sensing measurements. Geophys. Res. Lett., 29(16), $10-11$.

Sharp, M., L. Copland, K. Filbert, D. Burgess and S. Williamson. 2004. Recent changes in the extent and volume of Canadian Arctic glaciers. In Glaciological Data Report GD-32. Boulder, $\mathrm{CO}$, National Snow and Ice Data Center, World Center for Glaciology.

Zhang, X., L.A. Vincent, W.D. Hogg and A. Niitsoo. 2000. Temperature and precipitation trends in Canada during the 20th century. Atmosphere-Ocean, 38(3), 395-429. 